\title{
SOVIET UNION'S BALKAN OPENING DURING THE KHRUSHCHEV PERIOD: ATTEMPTS TO RESTORE RELATIONS WITH TURKEY, YUGOSLAVIA AND GREECE*
}

\author{
Dr. Öğr. Üyesi Fatma Ası Kelkitti \\ İstanbul Arel Üniversitesi \\ Iktisadi ve İdari Bilimler Fakültesi \\ ORCID: 0000-0002-0164-8736
}

\begin{abstract}
The death of Stalin and Khrushchev's taking the helm of the Soviet Union following outmatching of his rivals brought out a new foreign policy in the country in the early Cold War period which was called peaceful co-existence. The new foreign policy line anticipated foundation of manageable relations with the Western bloc countries without losing the revolutionary ardor to beat them in economic well-being, scientific progress and cultural development. A significant ramification of peaceful coexistence policy became the Soviet Union's endeavor to straighten out its knotty relations with Turkey, Yugoslavia and Greece which had gone downhill due to Stalin's immediate post-Second World War foreign policy decisions. This paper aims to cast light on the various diplomatic, economic and security initiatives taken by Moscow under the leadership of Khrushchev to release these three Balkan countries from the firm grip of the Western alliance and to gravitate them towards closer association with the Soviet Union.
\end{abstract}

Keywords: Soviet Union, Khrushchev, Turkey, Yugoslavia, Greece

Sovyetler Birliği’nin Kruşçev Dönemindeki Balkan Açılımı: Türkiye, Yugoslavya ve Yunanistan ile İlişkileri Düzeltme Çabaları

Öz

Stalin'in ölümü ve Kruşçev'in rakiplerine üstün gelerek Sovyetler Birliği’nin dümeninin başına geçmesinin ardından erken Soğuk Savas döneminde ülkede barıș içinde bir arada yașama adında yeni bir dıs politika ortaya çıktı. Yeni dış politika çizgisi Batı bloku ülkeleri ile onları ekonomik refah, bilimsel ilerleme ve kültürel gelişmede yenecek devrimci heyecanı kaybetmeden yönetilebilir ilişkiler kurulmasını öngörüyordu. Barış içinde bir arada yaşama politikasının önemli bir sonucu Sovyetler Birliği'nin Stalin'in İkinci Dünya Savaşı ertesinde aldığı dış politika kararlarından dolayı baş aşağı gitmiş olan Türkiye, Yugoslavya ve Yunanistan ile arasındaki çetrefilli ilişkileri düzeltme çabası oldu. Bu çalıșma Krușçev'in liderliği altında Moskova'nın bu üç Balkan ülkesini Batı ittifakının sıkı kıskacından çıkarıp Sovyetler Birliği ile daha yakın bir birlikteliğe yöneltmek için aldığı diplomatik, ekonomik ve güvenlik inisiyatiflerine $1 s ̧ ı$ tutmayı hedeflemektedir.

Anahtar Sözcükler: Sovyetler Birliği, Kruşçev, Türkiye, Yugoslavya, Yunanistan

* Makale geliş tarihi: 27.12.2017

Makale kabul tarihi: 11.04.2018 


\section{Soviet Union's Balkan Opening during the Khrushchev Period: Attempts to Restore Relations with Turkey, Yugoslavia and Greece*}

\section{Introduction}

The death of Stalin on March 5, 1953, gave rise to profound changes in both domestic and foreign policy of the Union of Soviet Socialist Republics. ${ }^{1}$ The Politburo of the Central Committee, renamed as Presidium in October 1952, came to the fore as the main decision-making body of the country after having been relegated to the background for nearly two decades. Malenkov appeared as the first among equals in a collective leadership by assuming the posts of Chairman of the Council of Ministers and ranking Secretary of the Central Committee. Beria (First Deputy Premier responsible for internal affairs), Molotov (First Deputy Premier responsible for foreign affairs) and Voroshilov (Chairman of the Presidium of the Supreme Soviet) stood out as other influential members of the Presidium lined up in a hierarchical fashion (Bociurkiw, 1960: 578). Khrushchev ranked fifth in order of precedence representing the newly-formed five-man Secretariat in the Presidium (Towster, 1954: 487).

The fierce power struggle among the heirs of Stalin came on the scene shortly after the introduction of the new structure. It started with Beria's ouster of the Presidium in June 1953 and his later execution in December 1953. Subsequently, a tacit rivalry ensued between Malenkov and Khrushchev disguised in divergence of opinion regarding the direction of the economic policy in Soviet Union. Malenkov's "New Course", the main content of which

* This article is a revised and extended version of the paper named "Soviet Union's Balkan Opening During the Khrushchev Period: Attempts to Restore Relations with Turkey, Yugoslavia and Greece" that was presented at The First of the Mülkiye Congress on International Relations: "The $100^{\text {th }}$ Anniversary of the October Revolution: The Soviet Union, the Cold War and the International System" which took place in Ankara University on 16-17 October 2017.

1 The Soviet Union, commonly used short name of the Union of Soviet Socialist Republics is preferred throughout this study. 
was revealed by him in a speech addressed to the Supreme Soviet on 8 August 1953, suggested the augmentation of investments in agriculture and consumerrelated sectors along with dramatic tax cuts and increase in the size of peasant private plots (Zubok, 2009: 96). This new economic policy which would be carried out by diversion of some of the resources from the heavy industry and defense to the agriculture and light industry aimed to raise the living standards in the country within a short span of time.

Khrushchev presented his counter plan to the Central Committee in February 1954 which anticipated expansion of agricultural output through tillage of uncultivated lands in the Soviet Union. This move would increase the food production across the country and would improve the living standards of the population without upsetting the military-industrial complex. His program which was dubbed later as the "Virgin and Idle Land Programme" was approved by a government and party decree on 28 March 1954 which envisaged the cultivation of 13 million-hectares land in the North Caucasus, the Volga, east and west Siberia, north Kazakhstan and the Far East (McCauley, 1994: 226). Malenkov, who lost the battle, resigned from premiership in February 1955 and moved to the position of Minister of Electrification (Taubman, 2003: 265). Khrushchev's ally, Minister of Defense Bulganin replaced him. Malenkov had also let go of his stint as the ranking Secretary of the Central Committee as early as 14 March 1953 and was succeeded by Khrushchev in September 1953. So in a short period of time, Khrushchev managed to either eliminate or pacify/persuade his competitors and strengthened his position in the Presidium.

Shortly after triumphing over rivals in the collective leadership, Khrushchev initiated a significant de-Stalinization campaign within the party which precipitated rehabilitation of some victims of the Stalinist period, release of many political prisoners and return of exiled Soviet citizens to their homelands. These moves, while leading to a gradual liberalization in the political life of the Soviet Union, provided Khrushchev with the requisite respite to launch some economic reforms and agricultural projects.

Khrushchev's imprint on Soviet foreign policy became his introduction of the doctrine of peaceful coexistence that envisaged workable association between the two rival political and economic systems. Although the term had been used both by Lenin and Stalin in previous occasions, Khrushchev ascribed a much more comprehensive meaning to the concept. Peaceful coexistence did not only mean the avoidance of military conflict between two competing blocs. It also foresaw economic, scientific and cultural cooperation between the members of these two different systems based on sovereign and mutually beneficial relations (Khrushchev, 1959: 55-68; Kende, 1968: 353). 
Soviet Union's change in foreign policy line could be attributed to three main reasons. First of all, development of sophisticated military technology including nuclear weapons both by the United States of America (USA) and the Soviet Union increased the risk of mutual annihilation in the event of a possible conflict. Secondly, emergence of independent states in Africa and Asia whetted the Soviet appetite for finding new allies that would extend support to the country regarding international matters that were deemed important. Therefore, Soviet Union decided to adopt a more conciliatory attitude to draw these neutral states into its fold. Lastly, Khrushchev was aware of the fact that the Soviet Union lagged behind the West in technological products and services despite impressive improvements in the defense industry. Thus, he wanted to sustain a less problematic relationship with the Western world in order to concentrate on internal development of the country.

Moscow contributed to the signing of the armistice in Korea in July 1953, hammered out the agreement which restored Austria's sovereignty and ensured its neutrality in May 1955 (Ferring, 1968: 657-658) and established diplomatic relations with West Germany in September 1955 in order to ease tensions with the Western bloc. The Soviet Union also bolstered its ties with the new sovereign states of Asia and Africa. High-level visits to these countries initiated the establishment of bilateral economic, technical and military ties. Moscow provided loans, grants, machinery, consultants and infrastructural support as well as military equipment to these nascent states hoping that they would follow its lead in their political life, economic development and international orientation.

The Western world, especially the USA suspected the genuineness of a change in foreign policy of the Soviet Union. Political realists such as George Kennan drew attention to the tightening Soviet noose around the necks of the Eastern and Central European countries, particularly Hungary and questioned the veracity of the Soviet peace offensive (Kennan, 1960: 180-182). Soviet military intervention in Hungary was assessed as a typical behavior of a relentless great power which aimed to maximize its power and security at all costs. Furthermore, Khrushchev's call to increase international trade through developing commercial ties between the Eastern and Western blocs did not receive a warm response from Kennan either, as for a great power like the Soviet Union economic interests had always been subservient to the political goals. According to this line of reasoning, Moscow did not enter into trade deals with other countries to meet real economic needs but to have a say in their foreign policy decisions (Kennan, 1960: 185-186).

Moscow pursued its new foreign policy line persistently and vigorously despite the Western concerns. An important offshoot of peaceful coexistence doctrine of the Soviet Union became the endeavor to smooth out the clouded 
relationship with some Balkan countries which were either firmly anchored to the Western bloc like Turkey and Greece or were entertaining close political and economic ties with the Western capitals like Yugoslavia. The Soviet Union's engagement with these three Balkan states had steered through a rocky course since the end of the Second World War. The Turkish-Soviet relations received a heavy blow in June 1945 after Moscow demanded the Turkish territories of Kars and Ardahan from Ankara along with revisions in the Montreux Convention of 1936 which guaranteed military bases for its navy. The Greek government had complained continuously between the years 1946 and 1949 about the Soviet support extended in the form of war materials, financial aid and diplomatic support to the unrelenting local communist groups which were refusing to accept its authority. Finally, relations with Yugoslavia got out of hand in 1948 after Stalin revealed his explicit discontent concerning the independent socialist path followed by Tito and decided to punish him with an economic blockade.

This paper will focus on the examination of various diplomatic, economic and security instruments utilized by the Soviet Union during the Khrushchev era to lure these three Balkan countries away from the Western world and to draw them closer to the Soviet line. The diplomatic tools included the Soviet acknowledgement of the Stalin-era ill-doings and offers of restoration of political ties to tidy up the unresolved issues with these countries. Economic instruments were made up of generous economic cooperation proposals in the form of grants and credits as well as extension of technical aid whereas security tools constituted the suggestion of a nuclear-weapon-free zone in the Balkan Peninsula. This study claimed that although these various Soviet initiatives contributed remarkably to the alleviation of the unpleasant legacy of the Stalin era, they however failed to convince Ankara, Belgrade and Athens to loosen up their multi-faceted ties with the Western bloc.

\section{New Leadership with New Diplomatic Initiatives}

On 30 May 1953, Molotov, the Minister of Foreign Affairs of the Soviet Union summoned the Turkish ambassador Faik Hozar to his office and submitted a note to him which backtracked on the June 1945 Soviet demands from Turkey and underlined that the Soviet Union had no territorial claims to Turkey. Moscow had decided that it was the right time to approach Ankara for rapprochement especially after Turkey appeared to be the only country from the 
non-communist world that sent a representative ${ }^{2}$ to the funeral ceremony of Stalin (Bilge-Criss, 2012: 18). Subsequently, the Soviet Union set about breaking the ice in its relationship with Turkey through words and deeds in this direction. In March 1954, a new ambassador, Boris Podtserob was appointed to Ankara to open a new chapter in diplomatic relations. On 29 October 1954, the Moscow Radio broadcasted a special program for the commemoration of the $31^{\text {st }}$ anniversary of the foundation of the Turkish Republic and recalled the erstwhile friendly relations with Ankara. It was also emphasized that the Soviet Union sought to restore political ties with Turkey, increase trade between the two countries and cooperate in the fields of technology and culture (Bilge, 1992: 339-340). Shortly after, on 7 November 1954, Bulganin accused Stalin of spoiling the Soviet Union's relations with its neighbors and declared that they were returning to Lenin's policy of good neighborhood and friendship with Iran and Turkey (Office of Current Intelligence, Central Intelligence Agency, 1955: $37)$.

Turkey's reaction to the Soviet diplomatic offensive was lukewarm at best. The almighty, formidable and demanding Soviet Union had presented the greatest threat to the newly independent, militarily backward and poor Turkey in the wake of the end of the Second World War. It was because of the Soviet moves which were considered as infringement on national sovereignty that Turkey had to let go of its cautious and balanced foreign policy and anchored itself firmly to the Western alliance system. Therefore, Moscow's call for better political, economic and socio-cultural relations which in the mid-to-long term aimed to orient Turkey towards a more equidistant position regarding its dealings with the Eastern and the Western blocs fell on deaf ears in Ankara until the late 1950s. Turkey consolidated its military ties with the USA both bilaterally and within the framework of the North Atlantic Treaty Organization (NATO) and entered into regional arrangements in the Balkans and the Middle East that drew reaction from the Soviet Union.

The Soviet Union pursued a three-pronged strategy to bend Turkish intransigence. Firstly, Moscow demonstrated its concern and dissatisfaction pertaining to NATO's deployment of nuclear weapons, intermediate-range ballistic missiles and other strategic military equipment on Turkish soil and the USA's utilization of Turkish airspace to carry out reconnaissance flights over the Soviet Union via diplomatic notes and declarations from high-ranking

2 A delegation headed by the Secretary-General of the Ministry of Foreign Affairs Cevat Açıkalın who had served as Turkey's Ambassador to the Soviet Union between 1942 and 1943 attended the funeral of Stalin. Turkey's dispatch of a delegation to the ceremony was appreciated by Molotov. See Hasanli, 2011: 369. 
figures. These documents and statements stressed that Turkey bore as much as responsibility as the USA for these border violations and was engaged in acts that were detrimental to the maintenance of friendly and peaceful relations with its northern neighbor (Ayın Tarihi 6 February 1956; Harris, 1974: 21).

Secondly, the Soviet Union strove to neutralize the regional security organizations spearheaded by Turkey at the behest of the USA in the Balkans and the Middle East through direct diplomacy as well as backroom negotiations. The Balkan Pact which came into existence on 28 February 1953 as a regional cooperation scheme aimed to boost collaboration between Turkey, Greece and Yugoslavia in the economic, technical and cultural spheres (Ministry of Foreign Affairs of the Republic of Serbia, 2009) and then transformed into a defense alliance on 9 August 1954 became defunct after Moscow launched a process of reconciliation with Yugoslavia which would induce Belgrade in a little while to show much more restraint in entering into a military cooperation with two NATO members. The Baghdad Pact, which was inaugurated on 24 February 1955 by Turkey, Iran, Iraq, Pakistan and the United Kingdom (UK) to arrest a possible Soviet expansion in the Middle East, came under serious attack not only from the Soviet Union but also from a significant regional power such as Egypt whose leader Nasser criticized the pact as an instrument of Western imperialism. Nasser's refusal to be part of a defense alliance established by former imperial masters against a distant Soviet peril whereas he perceived an imminent threat from Israel proved to be very useful to dissuade other Arab states from participating to the Baghdad Pact.

Lastly, although Moscow chastised Ankara because of its attachment to the NATO and tried to curb the impact of the regional mechanisms Turkey established at the instigation of the USA, it nevertheless stuck to its main target of finding a way to bring out a thaw in the relationship. Khrushchev, on various occasions acknowledged the Soviet responsibility for deterioration of the relations and underlined that they were ready and determined to rectify their error (Ulunian, 2003: 44; Dekmejian, 1968: 512; Hasanli, 2008: 132). Moreover, Voroshilov invited the Turkish Prime Minister Adnan Menderes and a Turkish parliamentary delegation to the Soviet Union in order to give a new momentum to political ties. Moscow also hinted that it was ready to finance some industrial projects in Turkey such as an oil refinery and a steel mill (Harris, 1974: 17).

The persistence and perseverance of the Soviet diplomatic demarches coupled with Turkey's increasing economic difficulties along with disagreements it had with its Western allies over Cyprus led Ankara to make room for Moscow in its foreign policy equation. In December 1959 Turkey's Minister of Health Lütfi Kurdar carried out the first minister-level visit to the Soviet Union after two decades. Menderes was planning to visit Moscow in 
July 1960 before he was ousted in a military coup that took place on 27 May 1960. The coup stalled but did not end the rapprochement process between Turkey and the Soviet Union. A Turkish parliamentary delegation headed by the leader of the Senate Suat Hayri Ürgüplü paid a 16-day visit to the Soviet Union in May-June 1963. The delegation was received by Khrushchev, Chairman of the Presidium of the Supreme Soviet Brezhnev and other highlevel Soviet officials. During the talks Khrushchev and his entourage underlined once more that they could extend financial aid to Turkey at more favorable conditions than the West (Oran, 1970: 83). Finally, Turkish Foreign Minister Feridun Cemal Erkin's October-November 1964 visit which called for stronger neighborly association, increased commercial relations and revived cultural ties between the two countries crowned the détente (Karpat, 1975: 92). Although Khrushchev was removed from power two weeks before Erkin's visit, he deserved considerable credit for restoration of political association with Turkey to normal if not cordial level.

The Soviet Union set its sights on Yugoslavia shortly after the reconciliation attempt with Turkey. Molotov called in the Yugoslav Charge d'Affaires Dragoje Djuric to his chambers on 6 June 1953 and conveyed his government's desire to exchange ambassadors with Yugoslavia again. Following a positive response from the Yugoslav side, the Soviet Union sent Vasily Valkov to Belgrade as the new Soviet Ambassador on 21 July 1953 whereas his Yugoslav counterpart Dobrivoje Vidic set foot in Moscow at the end of September 1953 (Rajak, 2004: 53). Moscow also took steps to curb the anti-Yugoslav propaganda conducted by anti-Titoist Yugoslav emigres by ending the broadcasts of Free Yugoslavia radio station and stopping the activities of the Association of Yugoslav Partisans (Radio Romania International, 2009; Rajak, 2004: 115). Moreover, the Soviet Union urged the fellow satellite states in Eastern Europe to normalize diplomatic relations with Yugoslavia.

Yugoslavia however, proved to be a hard nut to crack. The country had stood firm in the midst of various onslaughts directed from both the Soviet Union and Soviet allies and retained its independence in the last five years thanks to strategic geography, deft leadership and generous Western aid. Therefore, Belgrade received Soviet peace offensive with noticeable caution and hesitation. It took Khrushchev nearly one year and several exchanges of letters with the Yugoslav leader Tito to get invited to Yugoslavia to discuss lingering problems between the two countries and to pave the way for normalization of relations. 
Between 26 May and 2 June 1955 a high-ranking Soviet delegation ${ }^{3}$ headed by Khrushchev visited Yugoslavia. In both Khrushchev's speech made in airport just after his arrival in Belgrade and in the Belgrade Declaration signed between the two states at the end of the talks on June 2, the Soviet side taking into account the Yugoslav sensitivity, pledged to adhere to the principles of peaceful-coexistence, equality, respect for sovereignty and national independence and non-interference in internal affairs in its association with Yugoslavia (The New York Times, 27 May 1955; Clissold, 1975: 255). Yet, although the Soviet Union seemed to adopt an understanding attitude with regard to Yugoslavia's jealously guarded independence and its multi-faceted bonds with the Western world, Moscow had initiated the rapprochement process with Belgrade in order to redraw it into its fold and to enhance the Soviet bloc's geopolitical position in Southern Europe and the Balkans. The best way to realize this objective from the viewpoint of the Soviet leadership was to re-establish relations between the Communist Party of the Soviet Union (CPSU) and the League of Communists of Yugoslavia (LCY) which would help the Soviet leaders to get into close contact with the current and future cadres of the Yugoslav state and win them over to the cause of the Soviet Union. Tito, however, being aware of these designs, declined the Soviet overtures made in this direction during the Belgrade visit of 1955 . He did not also demonstrate much enthusiasm for participating to the Warsaw Pact, newly founded defense alliance of the Eastern bloc.

Khrushchev's next move became engaging in acts that would lead Tito to drop his guard and to soften up in his attitude towards the Soviet Union. Khrushchev acknowledged Stalin's part in the fall-out of 1948 in February 1956 during the $20^{\text {th }}$ Congress of the CPSU and disbanded the Cominform in April 1956 which had become a platform for the Eastern bloc to inveigh against the 'Yugoslavian heresy'. Finally, on 1 June 1956, one day before Tito's visit to the Soviet Union after a decade; Molotov, who had second thoughts concerning the reconciliation process with Yugoslavia, resigned from the post of Foreign Minister (Lees, 1997: 182). These political maneuvers buttressed by loan and credit promises by the Soviet Union which might be useful to decrease Yugoslav dependence on the Western financial help engendered a favorable response in Yugoslavia to the restoration of bilateral party links. With the Moscow Declaration signed on 20 June 1956, it was decided to re-establish

3 The Soviet delegation encompassed Khrushchev, Bulganin, Mikoyan (Vice President of the Council of Ministers and member of the Presidium), Shepilov (Member of the Central Committee and Editor-in-Chief of Pravda) and Gromyko (First Deputy Foreign Minister). 
connections between the CPSU and the LCY on the condition that they would be based on voluntariness, equality and friendly criticism (Clissold, 1975: 261).

The Soviet-Yugoslav rapprochement seemed to be on the right track when Tito left Moscow on 23 June 1956. Yet, mass protests broke out against the ruling regimes of Poland and Hungary in the summer and autumn of 1956 had adversary effects on the overall relationship between the two countries. The unrest in Poland was kept under control once a transfer of power to Gomulka had been accepted by Moscow. The upheaval in Hungary on the other hand, could be calmed down only after the intervention of Soviet military troops. The events in Poland and Hungary strengthened the hands of the hardliners in the Presidium such as Molotov and Kaganovich who attributed Moscow's erosion of authority in the Eastern European satellites to the toleration of the national communism of Yugoslavia. They also claimed that Yugoslav media, intellectuals as well as the diplomats in Budapest Embassy of Yugoslavia added fuel to the fire by backing up the riot in Hungary (Granville, 1998: 496). Yugoslavia had agreed to the Soviet intervention in Hungary, growing wary of the increasing anti-communist and nationalist tone of the Hungarian uprising, but Tito and his close associates' later speeches which blamed the systemic failures of the Soviet system for the crises in Eastern Europe triggered another wave of mutual criticisms, complaints and accusations which would cool down the rapprochement process for three years.

Khrushchev and Tito decided to seek a compromise following an encounter on the sidelines of a United Nations (UN) meeting in New York in September 1960 (Brown, 1962: 366). Yugoslav Foreign Minister Popovic went to Moscow in July 1961, carrying out the first high-level Yugoslav visit to the Soviet capital four years later. It was reciprocated by his Russian counterpart Gromyko's April 1962 visit to Belgrade which paved the way for Chairman of the Presidium of the Supreme Soviet Brezhnev's visit to the same destination five months later (Hasan, 1981: 113-116). Tito paid an unofficial visit to the Soviet Union in December 1962 and Khrushchev came to Belgrade in August 1963. In the course of the talks, the two leaders focused on their common positions pertaining to the existing international problems and eschewed from delving into complicated ideological discussions.

Khrushchev's second and more successful reconciliation initiative with Yugoslavia came after his realization that it was not possible to bring Yugoslavia back into the Soviet sphere of influence due to irreconcilable ideological differences and divergent perceptions of the international system. Nevertheless, Belgrade's burgeoning ties with the newly independent nations of Asia and Africa under the mantle of non-alignment movement might be of some help to Moscow as it was struggling to make inroads to these states to make headway in the competition with the Western powers. For Yugoslavia on 
the other hand, better political relations with the Soviet Union was valuable in terms of charting a balanced foreign policy line between the two blocs. Furthermore, reinvigoration of the political association with Moscow promised economic collaboration as well which was deemed significant at a time when Yugoslavia was apprehensive about the negative impact of the progressive integration of the European Economic Community on its trade dynamics (Kirby, 1966: 174). So by revising his initial goals and settling for less ambitious outcomes, Khrushchev managed to set the course on normalization of the political relationship with Yugoslavia before his ouster from the Soviet leadership.

The final target of Khrushchev's Balkan opening was Greece which, in addition to Turkey and Yugoslavia, were surrounded by allies of the Soviet Union, namely Albania and Bulgaria and which since July 1951 had been hosting the United Democratic Left (EDA) Party that was made up of many well-known center-left and leftist politicians who were former members of the Greek People's Liberation Army (ELAS) and looked favorably to the Soviet Union. Moscow kicked off its Greek initiative by raising its diplomatic representation level in Athens to the ambassadorial level on 23 July 1953 through appointment of Mikhail Sergueev as the Soviet Ambassador to Greece (The New York Times, 23 July 1953). Greece reciprocated in September of the same year by sending Alexandros Kountoumas to Moscow as the Greek Ambassador to the Soviet Union (Hatzivassiliou, 2006: 44).

Greece, similar to Turkey and Yugoslavia, hesitated for a while to respond to the Soviet overtures for normalization of relations. The bitter memories of the Civil War of 1946-1949 were still fresh in the minds of the Greek statesmen. Although Stalin had strong doubts concerning the ultimate victory of the Greek communists on the battlefield; he, nevertheless had lent financial and military help as well as diplomatic backing to them (Ulunian, 1996: 147-150). Moreover, the Soviet Union organized the evacuation of 100,000 communists and their sympathizers from Greece after their final defeat became inevitable in the late summer of 1949 (Karpozilos, 2014: 63). These people were sent to the Soviet Union and Eastern bloc countries. This situation incited further problems in the Greek-Soviet association as the Greek government later claimed that among those discharged from Greece were about 4,000 military officers who were being held in these countries against their will (Hatzivassiliou, 2006: 43). The Soviet Union, however, denied the Greek claims which became a point of discord between the two countries.

Another important thorn in the way of a possible rapprochement between Greece and the Soviet Union proved to be the threat Athens perceived from Moscow's most loyal ally in the Balkans, namely Bulgaria. Sofia was dragging foot regarding payment of reparations to Athens emanating from the Paris 
Peace Treaty of 1947, was consolidating its army with new men and weapons and was precipitating minor border incidents (Hatzivassiliou, 2006: 45). Moscow, recognizing that some kind of Greek-Bulgarian reconciliation was needed to warm things up for a future Greek-Soviet rapprochement induced Bulgaria to straighten out kinks in its interaction with Greece. Accordingly, in September 1953, shortly after rekindling of Soviet-Greek diplomatic relations, Bulgaria, through the UN proposed the immediate full normalization of relations with Greece. The two countries signed an agreement that determined their frontier line as well as a bilateral commercial accord in December 1953 (Hatzivassiliou, 2006: 46). Finally, in May 1954 Bulgaria and Greece declared the re-establishment of bilateral diplomatic relations except exchange of ambassadors which would be subjected to the settlement of the reparation issue.

The relaxation of the tension in Greek-Bulgarian relationship along with Greece's going through of serious disagreements with the USA, the UK and Turkey on Cyprus matter led Athens to search ways for entering a gradual compromise with the Soviet Union. Within this context, the Soviet Foreign Minister Shepilov was received by the Premier Karamanlis and the Foreign Minister Averoff-Tossizza in June 1956. Shepilov during the meetings underlined that the Soviet Union would like to base its relations with Greece on the principles of peaceful coexistence, reciprocal respect of independence and territorial integrity and non-interference in internal affairs (Sedgwick, 1956). The Soviet side also stated its readiness to extend economic and technical assistance to Greece (Raymond, 1956).

Shepilov's visit to Greece gave way to increased political exchange between the two countries in the coming years. The EDA's remarkable election success in 1958 and its elevation to the status of major opposition party in the Parliament following its criticisms about Greece's economic and military overdependence on the USA coupled with the increasing popular discontent regarding the USA's handling of the Cyprus issue led even some of the conservative Greek politicians such as Markezinis and Venizelos to give a try to the betterment of relations with the Soviet Union. They visited Moscow in 1959 and 1960 respectively and were welcomed by Khrushchev and other highranking Soviet officials (Rizas, 2013: 65-66).

With the establishment of the Republic of Cyprus on 16 August 1960 as a bi-communal state in which the authority was shared by the Greek and Turkish Cypriots, the grueling matter of Cyprus seemed to be off the agenda of the international society. However, communal violence flared up at the end of 1963 again shortly after President Makarios' declaration of amendments in the constitution in favor of the Greek Cypriots. The Soviet Union made use of this situation to get closer to Greece. Moscow offered humanitarian assistance and construction material as well as weapons to the Greek Cypriots through German 
Democratic Republic (GDR) and Czechoslovakia (Stergiou, 2007: 94). Furthermore, Soviet Union's emphasis on sovereignty and independence of the Republic of Cyprus and its objection to any possible military intervention on the island was appealing to both Greece and the Greek Cypriots. All in all, Moscow's influence on the Bulgarian-Greek reconciliation process as well as its standing concerning the Cyprus issue had positive impact on the overall Soviet-Greek association and could be named as Khrushchev's major contribution to the establishment of better political relations between Greece and the Soviet Union.

The Soviet Union with Khrushchev at the helm put a lot of time and effort into re-establishment of good rapport with Greece, Turkey and Yugoslavia. Turkey, sharing a common border with the Soviet Union, was still apprehensive of the Soviet military potential and demonstrated obvious reluctance to the normalization of political relations with Moscow. However, frustration with its NATO allies over the matter of Cyprus as well as the serious economic difficulties experienced at home would urge Turkey to change its decision in the early 1960s. For Yugoslavia restoration of friendly ties with the Soviet Union was conditional on Moscow's recognition of Belgrade's different road to socialism. When the Soviet Union accepted this fact finally towards the end of 1960, better political association with Yugoslavia could be set up. Greece, on the other hand, became much more malleable to Soviet reconciliation onslaughts as of late 1950s concomitant to the growing power of the leftist forces in its political life and increasing alienation from the NATO allies due to the eruption of the Cyprus crisis.

The Khrushchev period in the Soviet Union was marked with significant progress towards establishment of at least a working association with the former adversaries in the Balkans. Khrushchev owed this success not only to diplomatic initiatives but also to offers of economic and technical assistance to these countries. Therefore, the following part of the paper will examine the economic tools used by the Soviet Union to back up its rapprochement attempts with Greece, Turkey and Yugoslavia.

\section{Employment of Economic Instruments for Political Gains}

The Soviet Union decided to utilize bilateral trade, financial aid in the form of grants and credits along with technical help in order to complement its diplomatic initiatives in the post-Stalin period. Accordingly, in April 1953, at the time of the conference on East-West European trade organized by the UN Economic Commission for Europe in Geneva, the Soviet officials expressed their readiness to import not only industrial goods but also consumer products 
such as foodstuffs and textiles which were produced by the less-developed members of the non-communist world extensively (Zyzniewski, 1958: 225). They also hammered out many bilateral trade deals with these countries. Furthermore, in July 1953, the Soviet representative to the UN Economic and Social Council revealed that the Soviet Union would contribute to the programs that would provide technical assistance to the underdeveloped states (Porter, 1984: 16).

Greece, Turkey and Yugoslavia took their share of this Soviet economic offensive starting with the early 1950s. The Soviet Union stressed that its prospective financial aid schemes would encompass more advantageous terms than the economic assistance packages presented to them by their Western allies. Athens, Ankara and Belgrade however, were concerned about the possible political demands that might be tied up to the economic support programs of the Soviet Union. Yet, growing financial difficulties at home coupled with unwillingness of the advanced economies of the Western world to channel financial resources into the realization of industrial projects in these countries prevailed over worries in the end and the Soviet Union succeeded in initiating economic cooperation process with each country in one way or another.

The Soviet overtures to Turkey in the economic field picked up speed following Nikita Rijov's appointment as the new Soviet Ambassador to Turkey in April 1957. Rijov was a well-known figure among government circles in Ankara as he had worked as assistant to the First Engineer at the textile factory in Kayseri between the years 1935 and 1936 (Committee of Political Adviser, NATO, 1958). The factory was accepted as one of the successful early Republican investments in Turkey that was founded with the support of Soviet credit in the heydays of the Turkish-Russian relations. Shortly after his inauguration Rijov came forward with proposals to revive economic collaboration between the two countries. The Soviet offer came at a time when the USA decreased financial aid to Turkey and made it conditional on revision of macroeconomic policies of the government. Washington avoided Turkish calls for providing funds to industrial projects as well. ${ }^{4}$

4 Newspaper articles which compared Soviet aid to the Third World countries with the American loans lent to Turkey began to appear in the Turkish press in mid1950s. In one of these articles, a prominent writer, Falih Rifk1 Atay wrote that the Soviet Union was on the eve of providing credit to a steel mill project in India which was worth much more than the loan Turkey requested from the American banks. See Dünya, 17 June 1955. 
Turkey decided to give a try to the Soviet industrial assistance in July 1957. Turkish Commercial Bank ${ }^{5}$ signed an agreement with the Soviet Union to build a glass factory in Çayırova. Moscow gave Turkey a loan of 3.4 million rubles at 2.5 per cent interest for three years (Tellal, 2009: 518). The Soviet firm Technoexport provided the factory with the latest Soviet technology and educated 60 workers in Soviet factories which used similar technology (Wallace, 1990: 126-127). The factory went into operation in 1961 and by January 1962 it had started to export some of its products to the USA though in small quantities.

Turkey was impressed with business-like and cooperative attitude of the Soviet officials and technicians. Following the Çayırova experience Turkish Sümerbank too, decided to buy its equipment from Technoexport and the expansion work of the Beykoz Leather and Shoe Factory was awarded to another Soviet company in 1960. (Tellal, 2009: 782). In March 1960 Turkey signed barter agreements with Poland and the Soviet Union and began to send wool, cotton, leather and fruits to these countries in exchange of machinery, metals and chemical products (Milliyet, 15 March 1960). A similar trade deal with the Soviet Union was concluded in 1964 as well. By the end of the year, bilateral Turkish-Soviet trade had come at 24 million dollars, making up approximately 3 per cent of Turkey's total trade (Murarka, 1965: 236; Turkish Statistical Institute, 2013: 2). Although the figures seemed to be low, the complementary character of the Turkish and Soviet economies promised further room for development of bilateral trade.

The Soviet Union's economic offensive on Yugoslavia commenced with the dispatch of a Soviet trade delegation to Belgrade in September 1954. After contentious negotiations, a barter agreement was signed between the Soviet delegation and Yugoslav Chamber of Foreign Trade on 10 October 1954 under which Yugoslavia would send meat, tobacco, hemp, ethyl alcohol and soda to the Soviet Union and in return would receive crude oil, cotton, manganese, ore, coal and newsprint (World Trade Organization, 1954: 19; Hasan, 1981: 97). Shortly after the re-vitalization of Soviet-Yugoslav commercial ties, Eastern bloc members such as Bulgaria, Hungary, Czechoslovakia and GDR clinched similar deals with Yugoslavia (Ayın Tarihi, 15 January 1955; Ayın Tarihi, 16 March 1955; Hasan, 1981: 97).

5 The Chairman of the Turkish Commercial Bank at that time was Tevfik Rüştü Aras who had served as Turkey's Foreign Minister between 1925 and 1938. Aras put signature on the Treaty of Friendship and Neutrality with the Soviet Union in 1925 and was known as one of the most pro-Soviet statesmen in Turkey. He, therefore, championed the restoration of Turkish-Russian ties feverishly. 
Moscow's second move was to write off Belgrade's 90-million-dollar debt in July 1955 and to offer credit and industrial help to the country through new agreements hammered out in September 1955, January 1956 and August 1956. The September 1955 arrangement envisaged the grant of a 54-milliondollar credit to Yugoslavia to finance the purchase of coal, oil, cotton and some other raw materials during the next three years (National Intelligence Council, 2006: 204). A new loan of 110 million dollars was awarded to Belgrade as well to cover Soviet technical assistance and equipment for the building of three fertilizer plants, a power station and the modernization of three mines between the years 1958 and 1964 (Lovitt, 1958: 156). In August 1956, this time with the contribution of GDR, an additional credit of 175 million dollars was extended to Yugoslavia for the construction of a combined hydroelectric and aluminium plant project in Niksic. The Yugoslav government took a lot of fancy to this project as it would serve two crucial purposes for the country. Firstly, it would help the Yugoslavs to utilize from their untapped abundant bauxite deposits and hydroelectric power potential which would contribute efforts to cope with balance of payments difficulties that stemmed from the country's huge debt to the Western countries especially to West Germany and the UK (Lovitt, 1958: 156). Secondly, the prospective aluminium plant was considered by Tito as the building block of a future Yugoslavian armament industry which would ensure the country's complete independence from the possible encroachments of Eastern and the Western blocs (Rajak, 2004: 279).

It became clear however, within a short period of time that the SovietYugoslav economic collaboration, different from the Soviet Union's commercial and technical bonds with Turkey, was susceptible to the political atmosphere between the two states. The divergence of opinion between the Soviet Union and Yugoslavia regarding the reasons of the Hungarian unrest and Yugoslavia's refusal to accept Soviet Union as the leading country of the communist movement brought about a political rift between the two countries which had implications in the bilateral economic relations as well. So the economic aid agreements of 1955 and 1956 were either cancelled or delayed couple of times until an enduring rapprochement between the Soviet Union and Yugoslavia took place in the fall of 1960. Shortly after the second reconciliation, Moscow and Belgrade agreed on a five-year trade agreement in March 1961 which aimed to boost the bilateral trade to 800 million dollars (Hasan, 1981: 113). Yugoslavia also managed to receive invitation from COMECON (Council for Mutual Economic Assistance), the economic cooperation organization of the Eastern bloc in September 1964 in the wake of better political ties with the Soviet Union for a special kind of relationship which anticipated integration in the areas of trade, finance, currency and industry (Schiavone, 1981: 91). 
Greece established commercial ties with the Eastern European satellites ${ }^{6}$ and the Soviet Union earlier than Turkey and Yugoslavia. Athens and Moscow signed a bilateral trade deal in July 1953. It was followed by similar trade agreements with other Soviet bloc countries soon afterward except Albania. The ailing condition of the Greek economy devastated by invasion and civil war forced the Greek government to be receptive to any country that demonstrated willingness to buy its products. Yet, the economic interaction with the Eastern bloc was not without problems. There was delay in deliveries of Soviet and Polish goods to Greece which engendered dissatisfaction on the Greek side. Greece announced in March 1954 that it would stop the delivery of goods to Poland and to the Soviet Union on the grounds that these countries did not act in accordance with the signed deals (Hatzivassiliou, 2006: 45). The issue was resolved later however and Greece signed similar bilateral trade agreements with the Soviet Union in the succeeding years.

Greece sold tobacco, raisins, citrus fruits and rawhides to the Soviet Union whereas in return it imported petroleum products, timber, machinery and chemical products (Ayin Tarihi, 20 January 1957; Botsas, 1987: 222). Export of tobacco to the Soviet Union was especially important for Greece because Greek farmers had been encountering hurdles and lagging behind in their international competition with the American tobacco producers for a while. The volume of bilateral Greek-Soviet trade, despite falling behind the Soviet trade with Yugoslavia or with Turkey nevertheless increased steadily over the years. While the value of commercial exchanges between Athens and Moscow came at 3 million dollars in 1952, it rose up to nearly 11 million dollars in 1964, registering nearly a triple increase (Botsas, 1987: 225; Hatzivassiliou, 1995: 192).

The economic cooperation of Greece and the Soviet Union during the Khrushchev period remained limited to commercial intercourse. The Soviet Union, more than one occasion offered Greece financial aid, exchange of scientific and technical experience as well as training of specialists (Raymond, 1996). Moreover, Moscow also promised to carry out investments in the country which would help Athens to take significant steps towards industrialization (Rizas, 2013: 62). Greece, however, kept aloof from these proposals. It was deprived of not only Turkey's geostrategic position and territorial depth but also Yugoslavia's versatile foreign policy standing. Furthermore, being a small economy Greece was also worried about too much dependence on Soviet material help as the Yugoslav experience had

6 The first bilateral trade agreement was signed with Poland in 1952. See Hatzivassiliou, 2006: 43. 
demonstrated that the Soviet Union could easily tie up economic aid to political demands.

The Soviet Union benefited from economic tools to a large extent to ameliorate its impaired political interaction with Turkey, Yugoslavia and Greece in the post-Stalin era. Bilateral commercial ties were reinvigorated rapidly as the economies of the Soviet Union and these three Balkan states were quite complementary. They provided agricultural products and textiles to the Soviet Union in exchange of industrial goods and raw materials. Moscow also helped to install significant industrial investments in Turkey and Yugoslavia which enhanced its credibility among governing circles in these countries. Yet, the Soviet Union's politicization of its economic aid to Yugoslavia in the wake of the Hungarian crisis hindered the further improvement of both political and economic bonds with Belgrade. It also generated a more reserved approach especially in Greece towards Soviet calls for more collaboration in the economic field.

The final move made by the Soviet Union to draw Turkey, Yugoslavia and Greece closer to its side during Khrushchev years was its suggestion of establishment of a nuclear-weapon-free zone in the Balkans which would bring together these three states along with the communist members of the Balkan Peninsula. The final part of the paper is devoted to the examination of this initiative that was presented to enhance tranquility of the Soviet Union's southern borders as well as to reduce the security risks and threats of its Balkan allies.

\section{Striving for Formation of a Nuclear-Weapon- Free Zone in the Balkans}

The Soviet Union's scaling down of its military force and its presentation of disarmament proposals at the UN in the second part of the 1950s along with the calls coming from both Moscow and Eastern European capitals for creation of nuclear-weapon-free zones in various parts of Europe could be evaluated as another component of Khrushchev's peaceful coexistence policy, revealing itself this time in the security domain.

Between the years 1955 and 1957 the Soviet Union announced to reduce its troop strength by nearly two million men (Wolfe, 1970: 164-166). It submitted disarmament plans to the UN in the fall of 1956 and in the spring and summer of 1957 which proposed armed forces reductions in the armies of the USA, the Soviet Union, the UK, France and China, banning of nuclear weapons in two years' time and curtailment of NATO and Warsaw Pact troops (Stefancic, 1988: 402). These proposals were succeeded by Polish Premier 
Gomulka's call to the Scandinavian countries in September 1957 to remove nuclear weapons from their territories and his Foreign Minister Rapacki's offer in October 1957 to establish a denuclearized zone in Central Europe which would comprise of the territories of Poland, Czechoslovakia, East Germany and West Germany (Sander, 1969: 148).

The Soviet Union and the Eastern European satellites had manifested superiority over the Western alliance in terms of conventional military capacity. Moscow also possessed significant arsenal of nuclear weapons and in October 1957 launched the Sputnik, the world's first intercontinental ballistic missile with striking capability to hit the US territory. Hence, Moscow's disarmament and nuclear-weapon-free zone offers were appraised by the USA and its European partners as subtle attempts to enervate the military capacity of the Western alliance.

Moscow, however, did not give up easily and decided to try its chance in the Balkan region with limited objectives. In September 1957, the Romanian Premier Stoica sent notes to Albania, Bulgaria, Greece, Turkey and Yugoslavia to come together in a regional conference where they would discuss their mutual problems (Pelt, 2006: 178). The negative responses of Greece and Turkey made convening of the conference impossible. Yet, Stoica came up with another proposal in June 1959 addressed not only to the Balkan countries but also to Italy. His plan suggested the signing of a collective security treaty to settle all differences by peaceful means among these countries and the withdrawal of all nuclear weapons, rockets and missiles from their territories which would harbinger the formation of a nuclear-weapon-free zone in the Balkans and Adriatic area (Sander, 1966: 114-115).

The Romanian proposal of June 1959 was introduced shortly after Khrushchev's statement that in the event of establishment of rocket bases in Greece and Italy, the Soviet Union would be forced to set up similar bases in Albania and Bulgaria as a countermeasure (The New York Times, 7 June 1959). Khrushchev was here referring to the preparations made by NATO for the deployment of Jupiter and Thor intermediate-range ballistic missiles in Greece, Italy and Turkey as a countermove to the launch of Sputnik. Furthermore, the matter of Cyprus which drove a wedge between Turkey and Greece and placed intra-bloc harmony at risk was on the way to settlement with the signing of the London-Zurich treaties in February 1959. Thus, Moscow felt the need to intervene and backed up the Romanian denuclearized zone plan with diplomatic notes transmitted to Greece, Italy, Turkey, France, the UK and the USA on 25 June 1959 (Klick, 1987: 113).

Albania and Bulgaria embraced the Romanian plan full-heartedly while Yugoslavia expressed satisfaction for the inclusion of Italy and Greece in a 
nuclear-weapon-free zone. Tito, however, criticized Khrushchev's intention of setting up bases in Albania and Bulgaria by stating that Yugoslavia would not consider itself secure as long as other surrounding countries were creating atomic bases (The New York Times, 9 June 1959).

Turkey, bordering the Soviet Union, looked askance at any denuclearization proposal that would skip the nuclear weaponry, missiles and rockets of Moscow. So, Turkey declined the offer on 13 July 1959 and accused the Soviet Union of trying to prevent Turkey from obtaining modern defense weapons while itself possessing many of them (The New York Times, 15 July 1959).

The Greek government was between a rock and a hard place at the time of Stoica's presentation of his Balkan nuclear-weapon-free zone proposal. The EDA was putting pressure on the Prime Minister Karamanlis not to accept NATO's deployment of intermediate-range ballistic missiles on the Greek soil and to give serious thought to the Romanian denuclearization proposal. To make matters worse, many groups in the center and even some rightist circles joined the ranks of EDA with regard to this issue because of their disappointment and frustration about the handling of the Cyprus matter by the USA and the UK. Yet, the threat coming from the north prevailed in the end and Greece rejected the denuclearization plan on 10 June 1959 pointing out that the regional situation was not yet ripe to carry out such an endeavor (Sander, 1969: 157). The Greek government was anxious about the growing manpower of the neighboring Bulgarian army which already had gained overwhelming supremacy in tanks and artillery over its Greek counterpart (Hatzivassiliou, 1995: 188). This uneasiness about the Bulgarian military ascendancy would also impel Greece to dismiss a Bulgarian bilateral non-aggression treaty offer in August 1959 on the grounds that signing a similar pact in 1938 had not stopped Bulgaria from invading Greece three years later (Hatzivassiliou, 1995: 189).

The Soviet attempts to set up a nuclear-weapon-free zone in the Balkans which would encompass Turkey, Yugoslavia and Greece as well as its Balkan allies of Albania, Bulgaria and Romania came to naught within a short period of time. Although the offer appealed to Yugoslavia which had serious concerns with regard to rapid militarization of both the Eastern and the Western blocs, both Turkey and Greece declined it in no uncertain terms. Turkey was not interested in any disarmament or denuclearization plan which would not include the Soviet Union whereas Greece was uncomfortable with the preponderance of Bulgaria in conventional military power and therefore wanted to be part of the NATO's nuclear shield. All in all, Khrushchev's Balkan nuclear-weapon-free zone idea proved to be less successful compared to his diplomatic initiatives and economic cooperation suggestions in maintaining a better relationship with Turkey, Greece and Yugoslavia. 


\section{Conclusion}

The end of the Stalin epoch and Khrushchev's victory over his competitors in the collective leadership heralded a new era for the Soviet Union which brought out significant changes in foreign policy outlook of the country. The new foreign policy doctrine, peaceful coexistence encompassed not only eschewal from entering into military conflict with the Western world but also foundation of functioning economic, scientific and cultural association with the capitalist countries without losing the zest to overpower them in the final analysis.

An important aspect of this new foreign policy orientation of the Soviet Union became restoration of the battered ties with three significant Balkan countries, Turkey, Yugoslavia and Greece by putting into use diplomatic initiatives, economic cooperation offers and regional denuclearization proposals. Turkey fed a sizeable army and hosted nuclear weapons and strategic missiles on its territory. Due to their common long border these were bothering issues for the Soviet Union and Moscow through its peace offensive aimed to reduce Turkey's loyalty to the Western alliance. Yugoslavia, despite accepting economic aid from the Western capitalist states had managed to retain a similar political and economic system with the Soviet Union and therefore became a significant target of Soviet overtures. Greece, on the other hand, bordered the Soviet Union's communist allies and also possessed significant leftist constituency that had strong qualms regarding the growing economic and military preponderance of the USA in the country. All these features made it another good candidate for being recipient of Soviet onslaughts.

The Soviet Union made remarkable headway in normalization of political relations with Turkey and Greece during the Khrushchev era. Bilateral diplomatic exchanges at the ministerial level were carried out after a long hiatus which relaxed the strained atmosphere of the Stalin years. Ascending commercial ties along with loan and technical help extended especially to Turkey facilitated the political rapprochement between the Soviet Union and these countries. The realization of a thaw in the Soviet-Yugoslav relationship however, took place later as it took some time for Khrushchev to come to the conclusion that Yugoslavia was keen on sustaining its peculiar brand of socialism and pursuing a non-aligned foreign policy line.

The Soviet Union's intention to secure its southern borders and to reduce the threat perception of its Balkan allies through the formation of a nuclearweapon-free zone did not realize. Although Yugoslavia was open to the discussion of the idea, neither Greece nor Turkey wished to let go of the security mantle of NATO as the Soviet Union's nuclear arsenal and Bulgaria's 
conventional military capabilities were intimidating enough for them to stick to their security ties with the USA and the Western alliance.

It was for sure that the Soviet Union made significant progress under the leadership of Khrushchev towards undoing the negative legacy of the Stalin period in its relations with Turkey, Greece and Yugoslavia. Yet, better political rapport and ascending economic ties with these countries fell short of making them loosening up their multi-faceted bonds with the West. Ankara and Athens and to a lesser extent Belgrade did not gravitate much towards Moscow regarding inter-bloc matters but they made good use of the rapprochement with Moscow to obtain more concessions from the Western alliance.

\section{Bibliography}

Ayın Tarihi, 15.01.1955

Ayın Tarihi, 16.03.1955.

Ayın Tarihi, 6.02.1956.

Ayın Tarihi, 20.01.1957.

Bilge, A. Suat (1992), Güç Komşuluk: Türkiye-Sovyetler Birliği Illişkileri, 1920-1964 (Ankara: Türkiye İş Bankası Kültür Yayınları).

Bilge-Criss, Nur (2012), “ Türkiye-NATO İttifakının Tarihsel Boyutu”, Uluslararası Iliş̧kiler, 9 (34): 1 28.

Bociurkiw, Bohdan R. (1960), "The Problem of Succession in the Soviet Political System: The Case of Khrushchev", The Canadian Journal of Economics and Political Science, 26 (4): 575591.

Botsas, Eleftherios N. (1987), "Greece and the East: The Trade Connection, 1851-1984", Journal of Modern Greek Studies, 5 (2): 207-235.

Brown, J. F. (1962), “A Soviet-Yugoslav Rapprochement?”, The World Today, 18 (9): 365-373.

Clissold, Stephen (1975), "Yugoslav and Soviet Leaders Agree to Bury the Hatchet and Pledge Respect for the Principles of Sovereignty, Equality, and Non-interference; the Belgrade Declaration, 2 June 1955", Clissold, Stephen (Ed.), Yugoslavia and the Soviet Union, 1939-1973: A Documentary Survey (London: Oxford University Press): 254-257.

Clissold, Stephen (1975), "Statement on Relations Between the LCY and the CPSU: The Moscow Declaration, 20 June 1956", Clissold, Stephen (Ed.), Yugoslavia and the Soviet Union, 1939-1973: A Documentary Survey (London: Oxford University Press): 261-262.

Committee of Political Adviser, NATO (1958), "Rijov Nikita Semenovic-Soviet Ambassador in Ankara", http://archives.nato.int/uploads/r/null/3/4/3486/AC_119-WP_58_11_9_ENG.pdf (21.08.2017).

Dekmejian, R. H. (1968), "Soviet-Turkish Relations and Politics in the Armenian SSR", Soviet Studies, 19 (4): 510-525. 
Dünya, 17.06.1955.

Ferring, Robert L. (1968), "The Austrian State Treaty of 1955 and the Cold War", The Western Political Quarterly, 21 (4): 651-667.

Granville, Johanna (1998), “Hungary, 1956: The Yugoslav Connection”, Europe-Asia Studies, 50 (3): 493-517.

Harris, George (1974), "Cross-Alliance Politics: Turkey and the Soviet Union”, The Turkish Yearbook of International Relations, 12: 1-32.

Hasan, Sabiha (1981), "Yugoslavia's Foreign Policy Under Tito (1945-1980) - I", Pakistan Horizon, 34 (3): 82-120.

Hasanli, Jamil (2008), "The 'Turkish Crisis' of the Cold War Period and the South Caucasian Republics", Part II, The Caucasus \& Globalization, 3 (1): 122-133.

Hasanli, Jamil (2011), Stalin and the Turkish Crisis of the Cold War, 1945-1953 (Lanham: Lexington Books).

Hatzivassiliou, Evanthis (1995), "Security and the European Option: Greek Foreign Policy, 195262", Journal of Contemporary History, 30 (1): 187-202.

Hatzivassiliou, Evanthis (2006), Greece and the Cold War: Front Line State, 1952-1967 (New York: Routledge).

Karpat, Kemal H. (1975), "Turkish Soviet Relations", Karpat, Kemal H. (Ed.), Turkey's Foreign Policy in Transition, 1950-1974 (Leiden: E. J. Brill): 73-107.

Karpozilos, Kostis (2014), "The Defeated of the Greek Civil War: From Fighters to Political Refugees in the Cold War", Journal of Cold War Studies, 16 (3): 62-87.

Kende, Istvan (1968), "Peaceful Co-Existence: Its Interpretation and Misinterpretation", Journal of Peace Research, 5 (4): 352-364.

Kennan, George F. (1960), "Peaceful Coexistence: A Western View", Foreign Affairs, 38 (2): 171190.

Khrushchev, Nikita S. (1959), "On Peaceful Coexistence”, Foreign Affairs, 38 (1): 53-70.

Kirby, Richard Paul (1966), "Tito and Khrushchev: Harmony and Discord" (M.A. Thesis, Carleton University).

Klick, Donna J. (1987), "A Balkan Nuclear Weapon-Free Zone: Viability of the Regime and Implications for Crisis Management", Journal of Peace Research, 24 (2): 111-124.

Lees, Lorraine M. (1997), Keeping Tito Afloat: The United States, Yugoslavia, and the Cold War (University Park: The Pennsylvania State University Press).

Lovitt, Craig E. (1958), “Yugoslavia and the Soviet Union”, Pakistan Horizon, 11 (3): 156-165.

McCauley, Martin (1994), The Soviet Union 1917-1991 (London: Longman).

Milliyet, 15.03.1960.

Ministry of Foreign Affairs of the Republic of Serbia (2009), "Treaty of Friendship and Collaboration Between the Federal People's Republic of Yugoslavia, the Kingdom of Greece and the Turkish Republic Signed at Ankara on 28 February 1953", http://www.mfa.gov.rs/en/diplomatic-tradition/historical-diplomatic-235-papers/39-ugovorprijateljstvo-1953 (27.07.2017).

Murarka, Dev (1965), "The Soviet-Turkish Rapprochement", The Contemporary Review, 207 (1198): 235-238. 
National Intelligence Council (2006), From "National Communism" to National Collapse: US Intelligence Community Estimative Products on Yugoslavia, 1948-1990 (Pittsburgh: National Intelligence Council).

Office of Current Intelligence, Central Intelligence Agency (1955), "Resignation of Malenkov", https://www.cia.gov/library/readingroom/docs/caesar-12.pdf (26.07.2017).

Oran, Baskın (1970), “Türkiye'nin 'Kuzeydeki Büyük Komşu Sorunu’ Nedir?”, Ankara Üniversitesi Siyasal Bilgiler Fakültesi Dergisi, 25 (1): 41-93.

Pelt, Mogens (2006), Tying Greece to the West: US-West German-Greek Relations 1949-1974 (Copenhagen: Museum Tusculanum Press and University of Copenhagen).

Porter, Bruce D. (1984), The USSR in Third World Conflicts: Soviet Arms and Diplomacy in Local Wars 1945-1980 (Cambridge: Cambridge University Press).

Radio Romania International (2009), "Radio Free Yugoslavia", http://old.rri.ro/arhart.shtml? lang=1\&sec=9\&art=21162 (14.04.2018).

Rajak, Svetozar (2004), "Yugoslav-Soviet Relations, 1953-1957: Normalization, Comradeship, Confrontation" (Ph.D. Thesis, London School of Economics and Political Science).

Raymond, Jack (10.07.1956), "Moscow in Offer of Aid to Greece", The New York Times.

Rizas, Sotiris (2013), "Domestic and External Factors in Greece's Relations with the Soviet Union: Early Cold War to Detente", Mediterranean Quarterly, 24 (1): 57-80.

Sander, Oral (1966), "The Balkan Cooperation in Perspective", The Turkish Yearbook of International Relations, 7: 104-120.

Sander, Oral (1969), Balkan Gelişmeleri ve Türkiye (1945-1965) (Ankara: Sevinç Matbaası).

Schiavone, Giuseppe (1981), The Institutions of Comecon (London: The Macmillan Press).

Sedgwick, A. C. (29.06.1956), "Shepilov Confers with Greek Chief", The New York Times.

Stefancic, David (1988), "The Rapacki Plan: A Case Study of East European Diplomacy", East European Quarterly, 21 (4): 401-412.

Stergiou, Andreas (2007), "Soviet Policy Towards Cyprus", The Cyprus Review, 19 (2): 83-106.

Taubman, William (2003), Khrushchev: The Man and His Era (New York: W.W. Norton \& Company).

Tellal, Erel (2009), "SSCB'yle İlişkiler”, Oran, Baskın (Ed.), Türk Dış Politikası: Kurtuluş Savaşından Bugüne Olgular, Belgeler, Yorumlar I (Istanbul: Illetişim Yayınları): 499-521 and 769-783.

The New York Times (23.07.1953), "Soviet Names Ambassador for Full Greek Relations".

The New York Times (27.05.1955), "Khrushchev's Statement in Belgrade”.

The New York Times (7.06.1959), "Khrushchev Plans Bases If West Bars Balkan Aim".

The New York Times (9.06.1959), "Atom-Free Balkans Supported by Tito".

The New York Times (15.07.1959), "Turks Rebuff Soviet: Reject Bid for Nuclear-Free BalkanAdriatic Zone".

Towster, Julian (1954), "The Soviet Union after Stalin: Leaders and Policies", The American Slavic and East European Review, 13 (4): 471-499.

Turkish Statistical Institute (2014), Foreign Trade Statistics Yearbook 2013 (Ankara: Turkish Statistical Institute Printing Division). 
Ulunian, Artiom A. (1996), "The Soviet Union and 'the Greek Question', 1946-53: Problems and Appraisals", Gori, Francesca and Silvio Pons (Eds.), The Soviet Union and Europe in the Cold War, 1943-1953 (London: Macmillan Press): 144-160.

Ulunian, Artiom A. (2003), "Soviet Cold War Perceptions of Turkey and Greece, 1945-58", Cold War History, 3 (2): 35-52.

Wallace, Cissy E. G. (1990), "Soviet Economic and Technical Cooperation with Developing Countries: The Turkish Case" (Ph.D. Thesis, London School of Economics and Political Science).

Wolfe, Thomas W. (1970), Soviet Power and Europe, 1945-1970 (Baltimore: Johns Hopkins University Press).

World Trade Organization (1954), "Index of Trade Agreements: July-December 1954", https://docs.wto.org/gattdocs/q/GG/MGT/55-7.PDF (15.04.2018).

Zubok, Vladislav M. (2009), A Failed Empire: The Soviet Union in the Cold War from Stalin to Gorbachev (Chapel Hill: The University of North Carolina Press).

Zyzniewski, Stanley J. (1958), "Soviet Foreign Economic Policy”, Political Science Quarterly, 73 (2): 206-233. 